\title{
The prevalence of HIV-1 DNA in AIDS-related lymphoma and Kaposi Sarcoma throughout the AIDS epidemic
}

\author{
Leanne C Huysentruyt ${ }^{1,3^{*}}$, Susanna Lamers ${ }^{2}$, Michael S McGrath ${ }^{1,3}$ \\ From 13th International Conference on Malignancies in AIDS and Other Acquired Immunodeficiencies \\ (ICMAOI) \\ Bethesda, MD, USA. 7-8 November 2011
}

\section{Background}

Chronic inflammation is linked to tumorigenesis for many cancer types and likely contributes to tumor development in the HIV-infected patient population. AIDSrelated lymphoma (ARL) and Kaposi Sarcoma (KS), two AIDS-defining cancers, are associated with the tumor viruses EBV and KSHV, respectively. However, EBV is only detectable in $\sim 40 \%$ of ARLs and KSHV alone is not sufficient for KS development. Recent studies have shown that HIV is localized to tumor associated macrophages (TAM), not malignant B cells, in a portion of EBV-negative ARLs suggesting, that HIV infected TAM may play a role in tumorigenesis. The goal of this research was to determine the prevalence of HIV+ ARL and KS throughout the AIDS epidemic and examine tumor associated HIV for unique genetic signatures.

\section{Material and methods}

Whole genomic amplified DNA from ARL and KS biopsies was used for quantitative HIV gag gene amplification. The 3' env-LTR segment of HIV-1 genomes from tumor and non-tumor tissues from two patients that died of ARL were sequenced and Bayesian phylogenies were inferred using BEAST. All specimens were provided by the AIDS and Cancer Specimen Resource.

\section{Results}

Of the 119 ARL and $91 \mathrm{KS}$ biopsies, 45\% and 40\% contained detectable HIV-1 DNA, respectively. There was a significant decrease in the prevalence of HIV-1 DNA

\footnotetext{
* Correspondence: huysentrut|@hemeonc.ucsf.edu

'Department of Medicine, Hematology and Oncology, University of

California, San Francisco, San Francisco, CA, USA

Full list of author information is available at the end of the article
}

positive ARL and KS cases in the post-HAART era (after 1996; ARL $=39 \%, \mathrm{KS}=16.7$ ) as compared to preHAART $(A R L=54 \%, K S=45 \%)$. Our data suggest the overall amount of HIV DNA is less in tumor biopsies from the post-HAART era. A subset of ARL contained extremely high levels of HIV-1 DNA ( $\sim 1$ copy/cell). In addition, visceral KS had a higher prevalence of HIV-1 DNA (51.9\%) as compared to skin KS (30.7\%). HIV sequence evolution analysis of metastatic ARLs revealed that HIV was compartmentalized within sites of lymphoma and was distinct from HIV present in nonlymphoma sites.

\section{Conclusions}

The prevalence of HIV-1 DNA positive ARLs declined in the post-HAART era, but not to the same extent as $\mathrm{KS}$, consistent with the incidence of both tumor types in the post-HAART era. Higher prevalence of HIV-1 DNA in visceral sites of $\mathrm{KS}$ and lymphoma specific-HIV sequences in sites of metastatic lymphoma suggests that HIV, especially HIV infected macrophages, may play a role in the pathogenesis of KS and ARL disease progression. Additionally, HIV-infected macrophages are a source of chronic inflammation that may further enhance tumorigenesis. Our data suggest a tumor specific form of HIV may be evolving within individuals who develop ARL.

\footnotetext{
Author details

${ }^{1}$ Department of Medicine, Hematology and Oncology, University of California, San Francisco, San Francisco, CA, USA. ${ }^{2}$ BiolnfoExperts, Thibodaux, LA, USA. ${ }^{3}$ West Coast AIDS and Cancer Specimen Resource, University of California, San Francisco, San Francisco, CA, USA.
} 
Submit your next manuscript to BioMed Central and take full advantage of:

- Convenient online submission

- Thorough peer review

- No space constraints or color figure charges

- Immediate publication on acceptance

- Inclusion in PubMed, CAS, Scopus and Google Scholar

- Research which is freely available for redistribution 